\title{
会 告沼formation
}

20007 , No. 6

学会カレンダー

ページ 号

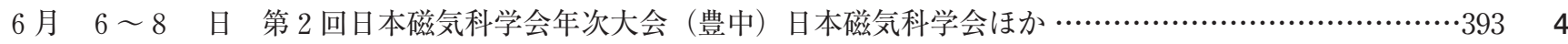

6 月 8 日 炭素材料学会先端科学技術講習会 2007 (東京) 炭素材料学会, 本会電池技術委員会・

キャパシタ技術委員会ほか ……460

6 月 $9 \sim 10$ 日 第24回ライラックセミナー・第 13 回若手研究者交流会 (小樽) 本会北海道支部 …………3 305

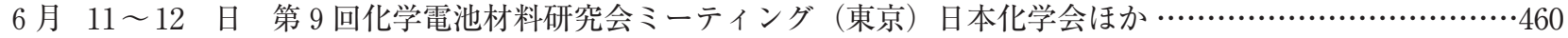

6 月 $11 \sim 15$ 日 第 18 回キャタリシススクール（東京）触媒学会ほか ……........................................306

6 月 $14 \sim 15$ 日 第31回有機電子移動化学討論会一エレクトロオーガニックケミストリー討論会（鳥取）

有機電子移動化学研究会, 本会有機電気化学研究会ほか ……305

6月 $15 \sim 16$ 日 第 3 回有機電子移動化学若手の会（鳥取）有機電子移動化学研究会,

本会有機電気化学研究会ほか……306

6 月 19 日 固体化学の新しい指針を探る研究会第57回定例研究会（東京）

本会固体化学の新しい指針を探る研究会……458

6月 $21 \sim 22$ 日 平成 19 年度日本セラミックス協会電子材料部会「セラミック電子材料入門講座」(東京)

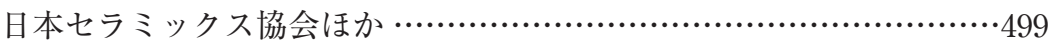

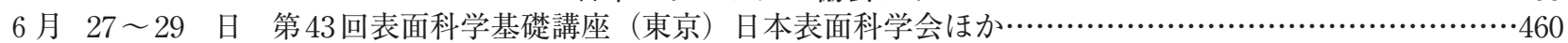

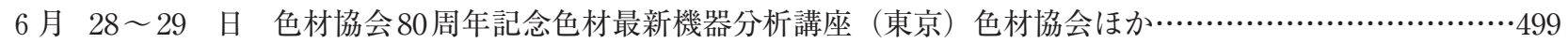

7 月 $2 \sim 3$ 日 センサ・マイクロマシン準部門平成 19 年度総合研究会（つくば）電気学会ほか $\cdots \cdots \cdot . \cdot V o l .74,990$

7 月 $2 \sim 4$ 日 第 20 回バイオメデイカル分析科学シシポジウム (八王子) 日本薬学会ほか…………………3 393

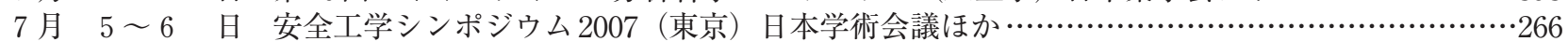

7 月 6 日 第20回イオン交換セミナー (東京) 日本イオン交換学会ほか……………………….......4 499

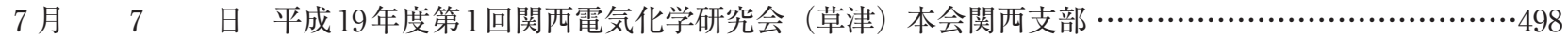

7 月 7 日 第44回化学関連支部合同九州大会（北九州）本会九州支部ほか..........................264 26, 503

7 月 $11 \sim 13$ 日 第33回フラーレン・ナノチューブ総合シンポジウム (福岡)

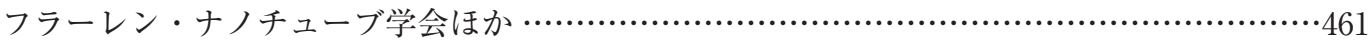

7 月 12 ～ 13 日 第 71 回半導体・集積回路技術シシポジウム（東京）本会電子材料委員会ほか …………………306

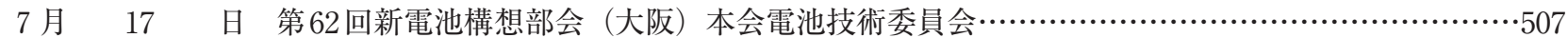

7 月 19 日 第 17 回電極材料研究会（さいたま）本会電解科学技術委員会……………………….......5 07

7 月 20 日 第 47 回有機電解合成公開セミナー（岡山）有機合成化学協会ほか……………………....461

7 月 27 日 日本真空協会関西支部・日本表面科学会関西支部合同セミナー 2007 (神戸) 日本真空協会ほか 499

8 月 $1 \sim 2$ 日 第 15 回希土類サマースクール (名古屋) 日本希土類学会ほか…………………………...5

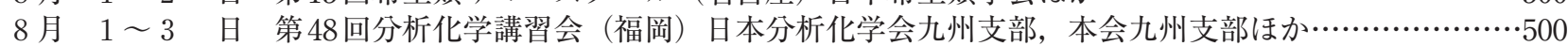

8 月 $5 \sim 10$ 日 第 2 回イオン液体国際会議（横浜）同組織委員会ほか ………………………………...4

8 月 $7 \sim 8$ 日 2007 電気化学セミナー3「初心者のための電気化学ワークショップ」(東京)

本会普及委員会ほか ……498

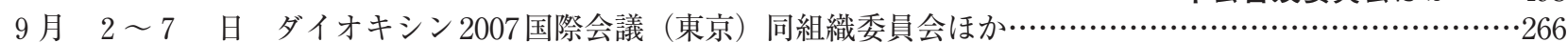

9 月 $5 \sim 8$ 日 第 17 回池谷コンファレンス・堂山シシポジウム (東京) 同組織委員会ほか…………………3 307

9 月 $12 \sim 14$ 日 日本セラミックス協会第20回秋季シンポジウム (名古屋)

日本セラミックス協会ほか $\cdots \cdots \cdot \cdots 394 \quad 4,461$

9 月 $17 \sim 19$ 日 第 43 回 X線分析討論会（京都） 日本分析化学会ほか

9 月 $18 \sim 21$ 日 2007 年国際固体素子・材料コンファレンス（SSDM2007）（つくば）応用物理学会ほか ……501

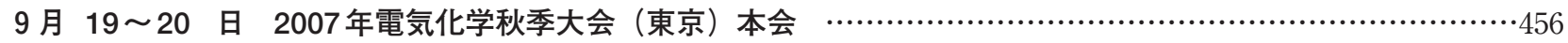

9 月 $19 \sim 20$ 日 第44回化学センサ研究発表会（東京）本会化学センサ研究会…………………………......458

9 月 $27 \sim 29$ 日 第 34 回アモルファスセミナー (宮城) 同実行委員会ほか……………………...............501

9 月 $28 \sim 29$ 日 第22回生体機能関連化学シシポジウム（仙台） 日本化学会ほか......................................3

10月 $1 \sim 3$ 日 第4 回熱測定討論会（札幌） 日本熱測定学会ほか……..........................................5

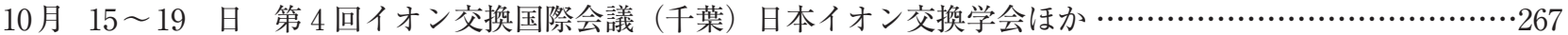

10月 $18 \sim 19$ 日 第27回エレクトロセラミックス研究討論会（東京）日本セラミックス協会ほか……………5 502

10月 29〜 11月 2 日 第 16 回二次イオン質量分析国際会議，第 6 回新材料・素子の原子レベル評価に関する

国際シンポジウム (金沢) 同組織委員会ほか ……………Vol.74, 990

11月 $10 １ 1$ 日 第38回中部化学関係学協会支部連合秋季大会（津）中部化学関係学協会支部連合協議会，

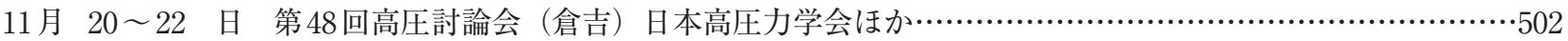

11月 $21 \sim 25$ 日 第30回溶液化学シンポジウム・JMLG/EMLGミーティング 2007 合同大会（福岡）

溶液化学研究会ほか ……461

12月 $3 \sim 7$ 日 第 17 回太陽光発電国際会議（福岡）同組織委員会ほか 
12月 $6 \sim 9$ 日 ソノケミストリー国際シンポジウム 2007 (京都) ソノケミストリー研究会ほか……………394 4

12月 $16 \sim 19$ 日 The 2nd International Conference on Physics of Solid State Ionics (2nd ICPSSI) (横浜)

同国際会議組織委員会ほか ……………...502

$-2008-$

11月 $9 \sim 13$ 日 表面科学とナノテクノロジーに関する国際シンポジウム（東京） 日本表面科学会ほか ………462 5

平成 20 年度電気化学会各賞推薦募集（締切平成 19 年 8 月 31 日 (金)) 4976

年会費の口座引落のお願い

平成19年度会費納入のお願い

Vol. 69, $505 \quad 6,575 \quad 7,648$

Vol.74, $992 \quad 12$

动今後の大会開催予定 放 電気化学会第 75 回大会 2008年電気化学秋季大会 電気化学会第 76 回大会 2009 年電気化学秋季大会 電気化学会第 77 回大会 2010 年電気化学秋季大会

\author{
平成 20 年 3 月 29 日（土） 31日（月）山梨大学工学部 \\ 平成 20 年 10 月 12 日（日）～17日（金）第 5 回日米合同大会・八ワイ予定 \\ 平成 21 年 (春) 京都大学予定 \\ 平成 21 年（秋）東京農工大学工学部予定 \\ 平成 22 年 (春) 北陸地区 \\ 平成 22 年（秋）神奈川工科大学予定
}

本会のホームページ http : //www.electrochem.jp

\author{
平成 20 年度電気化学会 \\ 学会賞, 学術賞, 技術賞, 進歩賞の推薦募集 \\ 推萀募集締切日：平成19年 8 月 31 日（金）
}

本会におきましては，これまで電気化学に関する産業・学術の進歩，発達に関し特に顕著な業績に対し，武井武，棚橋寅 五郎，佐野隆一元会長ならびに第 1 回化学センサ国際会議組織委員会からのご厚意による基金を基にして，学会賞・武井賞， 学術賞，技術賞・棚橋賞，進歩賞・佐野賞の 4 賞を贈り，これを表彰してまいりました。このたび平成 20 年度の各賞候補者 の募集を次により行います.

\title{
1. 電気化学会賞 ·武井賞
}

\section{平成 20 年度電気化学会各賞募集要領}

本会個人会員, 学生会員あるいは名誉会員であって, 電気化学および工業物理化学の進歩・発展に寄与する優れた研究を行い, そ

の業績を本会会誌ならびに関連学協会誌に発表した者に授与する.

\section{2. 電気化学会学術賞}

本会個人会員, 学生会員あるいは法人会員に所属する個人であって, 電気化学および工業物理化学の分野において先駆的な研究業 績をあげた，原則として50才以下の者に授与する.

\section{3. 電気化学会技術賞・棚橋賞}

本会個人会員，学生会員あるいは法人会員に所属する個人であって，電気化学および工業物理化学を基礎とする技術開発を行い， 顕著な業績をあげた者に授与する。ただし，その技術開発が共同で行われたものである場合は，受賞の対象はその代表者とする.

\section{4. 電気化学会進歩賞・佐野賞}

本会個人会員，学生会員あるいは法人会員に所属する個人であって，電気化学および工業物理化学に関する研究または，新しい技 術の開発を進め，その進歩が顕著であると認められる者に授与する．ただし，表彰式の行われる年の 4 月 1 日現在で年齢が満 $35 才$ 以下（1972年 4 月 2 日以降の出生の者）でなければならない.

\section{5. 表彰の時期}

各賞とも選考委員会において厳正な審査のうえ選定，明年第 75 回大会時に行います.

\section{6. 推薦の方法}

本会会員は，本会個人会員，学生会員あるいは法人会員に所属する個人を受賞候補者として，被推薦会員所属の支部長または専門 委員会委員長に推薦書，受賞の対象となる業績一覧表，推薦理由書を付し期限内にご推薦下さい.（技術賞に関しては，技術開発が 共同研究によって行われた場合には， 1 件につきその代表者 6 名以内をご推薦下さい. また，同一テーマで独立に行われた技術開発 を併せて 1 件として推薦することが出来ます）この場合封筒の表に必ず「○○賞推薦」と朱書願います．上記の推薦書類は本会表彰係 （１02-0074東京都千代田区九段南4-8-30アルス市ヶ谷202 TEL 03-3234-4213）宛てご請求下さい. また，選考資料として受賞の対象 となる業績に関する発表論文, その他の資料 2 部を添付願います。 なお, 添付資料等は返却いたしませんのであらかじめご了承下さ い.

\section{7. 推薦書提出締切日}

平成 19 年 8 月 31 日（金）までに各支部・専門委員会に必着のこと. 


\section{8. 推薦書提出先}

○北海道支部： $\overline{\mathbf{T}}$ 060-8628 札幌市北区北 13 条西 8 丁目 北海道大学大学院工学研究科 大塚研究室内（北海道地区）

○東北支部： $=980-8579$ 仙台市青葉区荒巻字青葉 06 東北大学大学院工学研究科 板谷研究室内（青森・岩手・秋田・山形・宮城 $\cdot$ 福島地区)

○関東支部： ₹ 102-0074 東京都千代田区九段南4-8-30 アルス市ヶ谷 202 電気化学会本部内（茨城・群馬・栃木・千葉・埼玉・東 京・神奈川・山梨地区)

○北陸支部： $=920-1192$ 金沢市角間町自然科学 1 号館 金沢大学大学院自然科学研究科 池田研究室内 （新潟・富山・石川・福井 地区)

○東海支部：干460-0008名古屋市中区栄2-17-22 中部科学技術センター内（静岡・長野・愛知・岐阜・三重地区）

○関西支部：干611-0011宇治市五ケ庄 京都大学エネルギー理工学研究所 尾形研究室内（滋賀・京都・大阪・奈良・和歌山・兵

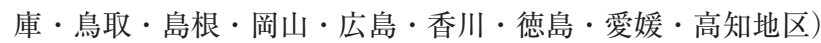

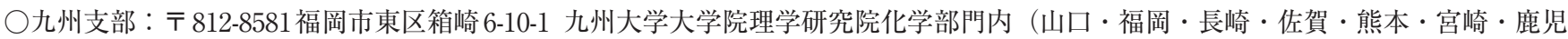
島・大分・沖縄地区)

○電池技術委員会：干816-8580春日市春日公園 6-1 九州大学先導物質化学研究所 山木研究室内

○腐食専門委員会：干565-0871吹田市山田丘 2-1 大阪大学大学院工学研究科 藤本研究室内

○溶融塩委員会：T 657-8502 神戸市灘区六甲台町 1-1 神戸大学大学院自然科学研究科 出来研究室内

○電子材料委員会：干102-0074東京都千代田区九段南4-8-30アルス市ヶ谷202 電気化学会本部内

○電解科学技術委員会：干 240-8501 横浜市保土ヶ谷区常盤台79-5 横浜国立大学大学院工学研究院 太田研究室内

○化学センサ研究会：干816-8580春日市春日公園 6-1 九州大学産学連携センター三浦研究室内

○キャパシタ技術委員会：干386-8567 上田市常田3-15-1 信州大学繊維学部精密素材工学科 高須研究室内

○エネルギー会議：干240-8501横浜市保土ケ谷区常盤台 79-5 横浜国立大学大学院工学研究院 太田研究室内

\section{平成 19 年度第1 回関西電気化学研究会}

主催 本会関西支部

日 時：7月 7日（土） $14: 00 \sim 17: 00$

場 所：立命館大学ローム記念館 びわこ・くさつキャンパス (草津市野路東 1-1-1)

1. 液相析出法におけるナノ界面の効果およびナノ材料のための 新規合成法の確立（神戸大院自然）中田明良

2. 高分子ヒドロゲル電解質を用いたアルカリ 2 次電池および電 気化学キャパシタの開発（阪府大院工）野原㯖士

3 . スクリーン印刷電極を用いる大腸菌由来の $16 \mathrm{~S} r \mathrm{rNA} の$ 電気 化学的検出（立命館大理工）白石晴樹

（講演終了後，簡単なビアパーティーを開きます）

○研究会参加費 無料, ビアパーティー 1,000円（当日受理）

○参加申込方法 6 月 29 日（金）までに氏名，所属，連絡先 (TEL, 所在地), 懇親会参加の有無を明記の上, 下記事務局ま でお申し込み下さい.

（連絡・申込先 干563-8577池田市緑丘1-8-31 産業技術総合研 究所ユビキタスエネルギー研究部門 倉谷健太郎（E-mail : kkuratani@aist.go.jp, TEL 072-751-9651, FAX 072-751-9629)

\section{7 電気化学セミナー 3 \\ 初心者のための電気化学ワークショップ 一実験を伴う電気化学基礎測定法一 \\ 主催 本会普及委員会 \\ 協賛 日本化学会ほか}

日 時：8月7日（火） 8 日 (水) $9: 30 \sim 16: 30$

場 所：東京大学工学部 5 号館（東京都文京区本郷 7-3-1）

第 1 日 $\cdot 7$ 日 (火)

1. 電気化学へのいざない (理科の実験から「電気化学」へ) [講義

2 . 三種の神器〔講義〕

「ポテンショスタット・ガルバノスタット」

「作用電極・基準電極・補助電極」
「セと試薬」

3.さあ実験だ! 電気化学の実験と研究ポイント〔講義】

4. 電気化学測定の基本〔実験演習〕

サイクリックボルタンメトリー, 電極電位の測定

第 2 日・ 8 日（水）

5.いろいろな電気化学システム〔実験演習】

午前と午後に異なるテーマを選択して頂きます（下記より2 つのテーマを選択し第 1 希望〜第 4 希望までご記入下さい)
A.インピーダンス法の金属腐食系への応用
B．定電流法を基本とする電池の充放電試験法
C. 燃料電池に関する測定法
D. 簡易型バイオセンサーの作製と評価
E. 太陽電池と光触媒
F．インピーダンス法による電解質の評価

○定員 45名 (先着順) 定員になり次第締切

但し, 学生の場合は, 参加者人数によりお断りする場合もあ りますので，ご了承願います.

（）参加費 個人会員 35,000 円，法人会員 45,000円，非会員 65,000 円, 学生会員 15,000円, 非会員学生 20,000円（テキスト・消費 税含む)

但し，「電気化学測定マニュアル (基礎編)」持参者は 2,000 円引き

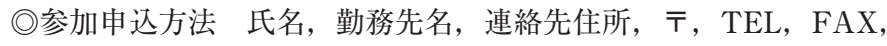
E-mail, 会員資格, 上記 5 の A Fのテーマより第 1 希望〜第 4 希望を明記の上, 費用を添え（現金書留または銀行振込）下 記宛お申し込み下さい。

なお，銀行振込は，三菱東京UFJ 銀行市ヶ谷支店・普通預金 口座（名義：電気化学会, 口座番号：014-0939526）にお願い 致します。

() 申込先干102-0074東京都千代田区九段南4-8-30 アルス市ヶ 谷202 電気化学会セミナー係（TEL 03-3234-4213, FAX 033234-3599) 
平成 19 年度日本セラミックス協会電子材料部会 セラミック電子材料入門講座一セラミックス電気特性の初歩

主催 日本セラミックス協会

協賛 本会ほか

日 時：6月21日（木） 22日（金）

場 所：日本セラミックス協会 3 階会議室

(東京都新宿区百人町 2-22-17)

第1日・21日（木） $11: 30 \sim 16: 30$

電子セラミックスの作成法（東海大）片山恵一

電子セラミックスの簡単なチェックーテス夕使用法など（東海大） 片山恵一

見て感じる電子セラミックスの扔もしろ現象 - “コンデンサは交 流を通す”など（千葉大）掛川一幸

第 2 日. 22 (金) $10: 30 \sim 15: 30$

絶縁体, 誘電体, 圧電体, 強誘電体とその測定方法（山梨大）和 田智志

半導体，イオン電導体とその測定方法（湘南工科大）藤津 悟

○定員 50名（先着順，定員になり次第締切）

（）参加費（消費税込）

官庁・学校関係：会員 10,000円，非会員 23,500円

学生：会員 3,000円，非会員 5,000円

企業関係：会員 20,000円，非会員33,500円

○电达先％169-0073東京都新宿区百人町2-22-17 日本セラミッ クス協会電子材料部会（TEL 03-3362-5231，FAX 03-3362-5714, E-mail : e-nyumonkoza@cersj.org)

振込先：三菱東京 UFJ 銀行新宿中央支店（普通） 5713561

日本セラミックス協会電子材料部会名義.

詳細はhttp://www.ceramic.or.jp/bdenshi/index_j.htmlをご覧 下さい.

\section{色材協会 80 周年記念色材最新機器分析講座}

主催 色材協会

協賛 本会ほか

日 時：6月28日 (木) 29日（金）

場＼cjkstart所：東京塗料会館（東京都渉谷区恵比寿 3-12-8）

第 1 日・28日（木） $10 ： 00 \sim 16: 40$

「ガスクロマトグラフィー」「液体クロマトグラフィー」

$\lceil\mathrm{TOF}-\mathrm{MS} 」 「$ 赤外分光法」「レーザーラマン分光法」

「紫外可視分光法」

第 2 日・29日（金） 9：00 17:00

「核磁気共鳴分光法」「電子スピン共鳴分光法」

$\lceil\mathrm{X}$ 線分析法」「X線光電子分光法」

「二次イオン質量分析法」

「透過電子顕微鏡および走査透過電子顕微鏡」

「走査電子顕微鏡」「走査プローブ顕微鏡」

「透過電子顕微鏡における試料作製法」

（）受講料（テキスト含む）会員 28,000円，会員外 38,000 円

（）申达先 干 150-0013 東京都渋谷区恵比寿 3-12-8 東京塗料会 館 色材協会（TEL 03-3443-2811, FAX 03-3443-3699, Email : shikizai@poem.ocn.ne.jp)

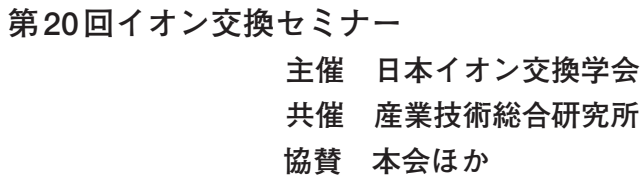

日 時：7月 6 日 (金) $10 ： 30 \sim 16 ： 45$

場 所：産業技術総合研究所・臨海副都心センター

(東京都江東区青海 2-41-6)

败テーマ イオン交換関連先端技術の紹介

1. 多孔性シリカの細孔構造と VOC 動的吸着特性（産総研）小 菅勝典

2. イオン交換に基づく超分子分析試薬の設計と機能評価（上智 大）早下隆士

3．燃料電池用水処理技術（栗田工業）佐藤重明

4. 超純水システムにおけるイオン交換装置とその運転事例（野 村マイクロ・サイエンス）八巻由孝

5 . 産官学の連携と知財立国へ向けての戦略（工業所有権情報 · 研修館）清水 勇

パネル討論「今後のイオン交換研究のあり方・人材育成・イオン 交換学会の役割」

（）懇親会 $17 ： 00 ＼mathrm{~(会 費 ~ 3,000 円 ） ~}$

(ㄱ)参加申込締切 6 月 29 日 (金)

○参加申込方法 Web（http://www.jaie.gr.jp）より. 必要事項 をご記入の上送信下さい。Webを利用されない場合はE-mailま たはFAX.

○参加費 予約：会員 5,000 円, 非会員 8,000円, 学生無料 予約外：10,000円．学生は予約外も無料

（）参加費支払方法 郵便振替（加入者番号：00120-2-155043, 加 入者名：イオン交換セミナー)

○申込先 干194-8543 町田市東玉川学園 3-3165 昭和薬科大学薬 品分析化学研究室内第 20 回イオン交換セミナー係 (TEL/FAX 042-721-1553, E-mail : zemi_20@jaie.gr.jp)

\section{日本真空協会関西支部・}

日本表面科学会関西支部合同セミナー 2007 21 世紀のゴールドラッシュー金のナノ科学・技術の最前線 主催 日本真空協会・日本表面科学会 協賛 本会ほか

日 時：7月27日 (金) $13: 00 \sim 17: 10$

場＼cjkstart所：神戸大学百年記念館（神戸市灘区六甲台町 1-1）

1. 開会の挨拶

2 . 現代の錬金術：金のナノ粒子とクラスター（首都大東京）春 田正毅

3.Auコロイドを使用したイムノクロマト診断薬への応用（田 中貴金属）岡本浩治

4. 微細金ナノ粒子超格子の創製戦略とナノ電子デバイス応用 (筑波大) 寺西利治

5. 濃厚貴金属ナノ粒子ペーストの調製と高機能コーティング材 料への応用（日本ペイント）石橋秀夫

6. 金微粒子を中心とした有機分子被膜貴金属微粒子の強磁性 （北陸先端大）堀 秀信

7. 閉会の挨拶

（）参加費 無料

○定員 200 名

(○参加申込方法 http://www.sssj.org/Kansai/goudou070727.html での ONLINE 申し达み。

(O)問合せ先 京都大学大学院工学研究科 鈴木基史 (TEL \& FAX 075-753-5196, E-mail：m-snki@me.kyoto-u.ac.jp) 


\section{第15回希土類サマースクール 希土類の機能と応用一基礎的知識と役割の理解 \\ 主催 日本希土類学会 \\ 協賛 本会ほか}

日 時：8月 1 日 (水) 2 日（木）

場＼cjkstart所：KKR ホテル名古屋（名古屋市中区三の丸 1-5-1）

TEL 052-201-3326, http://www.kkr-nagoya.jp/

1. 誘導体デバイスにおける希土類の役割 - ユビキタス社会に役 立つ希土類の機能 (東大先端研) 野口祐二

2. 光で見る希土類材料の構造と物性 - ラマン分光法を用いた希 土類材料評価のアプローチ（物材機構）長田 実

3 . 希土類錯体の機能一いかに役に立つか（阪市大院理）三宅 弘之

4. 希土類を使った有機合成一ほしいものだけをつくる（東大院 薬）松永茂樹

（）参加申达締切 7 月14日（土）定員 40名

（）参加費 (資料 ·宿泊費 (一泊三食付き) )

日本希土類学会会員 28,000 円, 共催 - 協賛学協会会員 30,000 円, 一般 36,000円，学生 18,000 円

(2) 申込先 T 565-0871吹田市山田丘2-1 大阪大学大学院工学研究 科応用化学専攻内 日本希土類学会事務局（TEL 06-6879-7352 または7353, FAX 06-6879-7354, E-mail：kidorui@ chem.eng.osaka-u.ac.jp）詳しくは希土類学会ホームページ http://kidorui.chem.eng.osaka-u.ac.jp/をご覧下さい.

\section{第48回分析化学講習会}

主催 日本分析化学会九州支部 共催 本会九州支部ほか

日 時：8月 1 日 (水) $~ 3$ 日（金）

場＼cjkstart所：九州大学西新プラザおよび伊都キャンパス

(福岡市早良区西新 2-16，福岡市西区元岡 744)

8 月 1 日（水）講義 $10 ： 00 \sim 17 ： 30$ 西新プラザ大会議室

1. ガスクロマトグラフィー<基礎と応用, 香気成分の分離・濃 縮，GC-MSなど> (九大院農) 下田満哉

2. 高速液体クロマトグラフィー<基礎と応用, 試料の前処理, 検出器など）（九大院薬）財津 潔

3. 原子スペクトル分析法＜基礎と応用，原子吸光，ICPなど $>$ (九大院理) 横山拓史

8 月 2 日（木）～3 日（金）実習 $10 ： 00 〜 16 ： 45$ 伊都キャンパ ス EN41棟実験室（各日 1 科目・2 日間で計 2 科目を選択）

1.ガスクロマトグラフィー（GC）（九大院農）下田満哉, 井倉 則之

基礎コース $[102$ 実験室 $]$

A. 化合物の同定（保持指標，マススペクトル)，B．定量分析 (内標準法), C. 試料導入法（スプリット・スプリットレ ス法)，D．固相マイクロ抽出法（簡易サンプリング法） 応用コース [102実験室 $]$

E. 香気成分の分離濃縮 (実試料), F. 香気成分の固相マイク 口抽出 (実試料), G. GC-MSによる香気成分の分析 (E. F. 調製品), H. 残留農薬分析の概要説明及びデータ解析

2. 高速液体クロマトグラフィー（HPLC）（九大院薬）財津 潔, 浜瀬健司

基礎コース $[101$ 実験室 $]$

A. HPLCの基礎（逆相 HPLC - UV 検出; 分離の最適化）, B. 逆相 HPLC (電気化学検出, 円二色性検出, 蛍光検出), C.
ゲル浸透・配位子交換クロマトグラフィー (示差屈折検出), D. 陰イオン交換クロマトグラフィー（電気伝導度検出） 応用コース $[101$ 実験室 $]$

E. 三次元検出, 固相抽出による試料の前処理, F. 高感度化と ハイスループット分析法

3. 原子スペクトル分析法（AAS）（九大院理）横山拓史, 岡上 吉広

基礎コース [102実験室 $]$

A. 微量金属成分分析のための基本操作法，B．フレーム原子 吸光法 (化学干渉とその除去), C. 水素化物発生 - 石英炬 原子吸光法 (七素の酸化数別定量), D. ICP 発光分析法 (高濃度マトリックス成分共存下の定量)

応用コース $[102$ 実験室 $]$

E. 固体試料中の重金属分析 (固体試料の溶液化, ICP 発光分 光法による定性分析，黒鉛炉原子吸光法による定量分析）

○使用機器島津製作所, 日本分光, 日立ハイテクノロジーズ, ジェイ・サイエンスラボ，東ソー，アジレント・テクノロジー， サーモフィッシャーサイエンティフィック，日本ダイオネクス， 日本ウォーターズ, 資生堂, 日本ミリポア, オルガノの提供に よる最新機器

○参加費 会員 32,000 円，会員外 42,000 円，学生 15,000 円

○参加申込方法 参加費を下記口座に送金後，以下の項目を明記 し，E-mailまたはFAXでお申し込み下さい。その際，お振込 みは受講者名で, また, E-mailの件名は “第48回分析化学講習 会申込”として下さい. (1)受講者氏名, (2)所属, (3)連絡先（†, 住所, TEL, FAX, E-mail), (4)第1～第3希望までの実習希望 科目組み合わせ（GC基礎，GC応用，HPLC 基礎，HPLC応用， $\mathrm{AAS}$ 基礎, AAS応用の 6 項目の中から 2 科目を選択 ; 応用コ ースは経験者に限定), (5)応用コースを選択される方は該当す る分析法の実務経験年数, (6)所属学協会名, (7)送金額および送 金日.

（）参加申込締切 7 月13日（金)

銀行口座：福岡銀行周船寺支店（普通） 0491139 第 48 回分析 化学講習会

(C)申达先 ₹ 819-0395 福岡市西区元岡744 九州大学大学院工学 研究院応用化学部門 第 48 回分析化学講習会事務局

(E-mail : bunkou48@cstf.kyushu-u.ac.jp, FAX 092-802-2889) (9)問合せ先 九州大学大学院工学研究院応用化学部門 今任稔彦 (TEL 092-802-2889), 中嶋 秀（TEL 092-802-2892）

\section{第43回 X線分析討論会}

ICXOM (19th International Congress on X-Ray Optics and Microanalysis）と併催

主催 日本分析化学会

共催 日本化学会ほか

協賛 本会ほか

日 時：9月17日（月） 19日（水）

場 所：京都大学百周年時計台記念館 $2 \mathrm{~F}$

京都大学工学部物理工学棟 $3 \mathrm{~F}$

(京都市左京区吉田本町)

方討論主題 $X$ 線光学と顕微分析（主題に関係なくX線分析の発 表を受け付けます)

（講演申达要領 1. 講演内容は未発表のものに限ります, 2. 招 待講演, 依頼講演, 口頭発表, ポスター発表からなります。す べて英語とします，3. 口頭発表は 1 講演 20 分（討論 5 分を含 
む）です。液晶プロジェクタ（Windows パソコンと PowerPointソフトを用意します)．OHP 希望の方は発表当日に ご連絡下さい，4. 申込み講演の採否およびプログラム編成は 実行委員会に一任願います，5，講演者は後日参加登録して下 さい.

(○)参加登録料 一般：予約 4,500 円，当日 6,000 円，学生 2,000 円， ミキサー参加費 1,000 円

○ミキサー 18 日 (火) 京都市内

○講演申込締切 6 月 20 日 (水) 必着

○講演要旨締切 6 月20日（水）

○ホテル予約締切 6 月 30 日（土）国際会議で確保したホテルの 詳細は下記web参照

(）プロシーディングス「X線分析の進歩」誌（和文）と Spectrochimica Acta Part B 誌（英文）を予定しています（原 稿締切 10 月 1 日).

(）講演申込方法 研究懇談会の下記 webページにアクセスし, Abstract見本を参考に必要事項を記入したAbstractを E-mail で送信して下さい。ややを得ない場合はFAXも受け付けます。 http://www.nims.go.jp/xray/xbunまたはhttp://www. process.mtl.kyoto-u.ac.jp/

○ Abstract送付先（原則としてE-mail添付） ₹ 606-8501 京都市 左京区吉田本町 京都大学大学院工学研究科材料工学専攻 河合 研究室気付 ICXOM国際会議実行委員会事務局（TEL 075-7535442, FAX 075-753-5436, E-mail : jun.kawai@materials.mbox. media.kyoto-u.ac.jp）メールの件名にICXOM発表申込とお書き 下さい.

○問合せ先 河合 潤（TEL 075-753-5442, FAX 075-753-5436, E-mail : jun.kawai@materials.mbox.media.kyoto-u.ac.jp）また は日本分析化学会（TEL 03-3490-3351, FAX 03-3490-3572, Email : hm_tanaka@jsac.or.jp)

\section{7 年国際固体素子・材料コンファレンス（SSDM2007） 主催 応用物理学会 協賛 本会ほか}

日 時：9月19日（水）～21日（金）本会議

9 月18日（火）ショートコース

場＼cjkstart所：つくば国際会議場（つくば市竹園2-20-3）

TEL 029-861-0001

主現在, 半導体エレクトロニクス産業は産業構造そのものの大変 革期を迎えており，本会議が果たすべきリーダシップに対する 期待は従来以上に高まっています。このような時代の要請に答 えるべく, SSDM は1999年より会議の対象分野を広げました。 すなわち，従来からの固体素子およびその材料に関する分野に 加えて, 回路とシステム分野（実装を含む）, 有機バイオ関連 分野などを強化することにし，下記の 13 のサブコミッティが設 置されています。

○プログラム・内容

Area1 Advanced Gate Stack/Si Processing Science

Area2 Characterization and Materials Engineering for Interconnect Integration

Area3 CMOS Devices/Device Physics

Area4 Advanced Memory Technology

Area5 Advanced Circuits and Systems

Area6 Compound Semiconductor Circuits, Electron Devices and Device Physics
Area7 Photonic Devices and Device Physics

Area8 Advanced Material Synthesis and Crystal Growth Technology

Area9 Physics and Applications of Novel Functional Materials and Devices

Area10 Organic Materials Science, Device Physics, and Applications

Area11 Micro/Nano Electromechanical and Bio-Systems (Devices)

Area12 Spintronic Materials and Devices

Area13 Applications of Nanotubes and Nanowires

（）参加費 一般 45,000 円（8/17 以前申込)，50,000円（8/17 以降 申込), 学生 7,000円

ショートコース：一般 15,000円，学生 3,000円

(〕参加申込方法 オンライン事前登録（7月上旬開始), または 会期中会場にて当日受付

(ㅇ)申达先 http://www.ssdm.jp

○問合せ先 ₹ 105-0003 東京都港区西新橋1-7-2 虎ノ門高木ビル (株インターグループ気付 SSDM 事務局（TEL 03-3597-1108， FAX 03-3597-1097, E-mail：ssdm@intergroup.co.jp) http://www.ssdm.jp

\section{第34回アモルファスセミナー 主催＼cjkstart第34回アモルファスセミナー実行委員会 共催 日本学術振興会ほか 協賛 本会ほか}

日 時：9月27日（木） 29日（土）

場＼cjkstart所：宮城蔵王遠刈田温泉遠刈田ホテルさんさ亭

（宮城県遠刈田郡蔵王町遠刈田温泉東裏 30)

URL : http://www.zao-sansatei.co.jp/

そアモルファスセミナーは，1974年の金沢での第 1 回以来，アモ ルファス物質及びナノ材料の研究者・技術者が一堂に会し, そ の基礎物性・評価からプロセス技術・デバイス応用までを幅広 く議論することを通して本分野の発展に貢献することを目的と して，年一回全国各地で開催されてきました。今年の第 34 回は， 9 月下旬に仙台近郊の遠刈田温泉にて開催予定です。今回はス タートアップセッションと本会議を一体化し，二泊三日の泊り 达みでゆったりと温泉に浸かりながら，最先端の議論と親交を 深める.

○参加費（宿泊・食事込み）一般 40,000円，学生 20,000円

()参加申込方法 本会議のホームページ http://www.xtalphys. imr.tohoku.ac.jp/amo2007/TOPALL.htm をご参照下さい.

○問合せ先 干980-8577仙台市青葉区片平2-1-1 東北大学金属材 料研究所 第34回アモルファスセミナー実行委員長 宇佐美徳 隆 (TEL 022-215-2012, FAX 022-215-2011, E-mail：xtal @imr.tohoku.ac.jp)

\section{第43 回熱測定討論会}

主催 日本熱測定学会 共催 日本化学会ほか 協賛 本会ほか

日 時：10月 1 日（月）〜 3 日（水）

場 所：札幌コンベンションセンター (札棍市白石区東札棍 6 条 1 丁目)

(〕)討論会の構成：特別講演，一般講演（口頭およびポスター）, 
イーブニングセッション「エネルギー・環境問題と熱測定」, 学 会賞・奨励賞の受賞講演.

（）一般講演テーマは，（1）熱測定基盤（測定法・装置を含む）， （2）磁性体・錯体，（3）液体·溶液·集合体·界面，（4）金 属・無機固体・セラミックス，(5）生体・医薬・食品，（6）高 分子・有機物，（7）エネルギー・環境に分類してプログラムを 編成します。

(）発表形式：一般講演は，口頭発表（講演 13 分＋討論 7 分）また はポスター発表とします。口頭発表できる講演数には限りがあ りますので，口頭発表希望でもポスター発表に変更させていた だく場合があります。合同セッションは口頭発表に限ります. 口頭発表は，原則として液晶プロジェクター使用とします。 OHP 使用を希望の方は発表申込用紙に必ずその旨を記入して下 さい.

(ㄱ)発表申达締切7月6日 (金)

(0)発表要旨原稿締切8月24日（金）

()参加予約申込締切9月10日（月）

(9)申达方法 日本熱測定学会のホームページから申达様式を取り 寄せて記入の上，電子メールの添付ファイルとして送付（宛先 netsu@mbd.nifty.com)

（）参加登録費（要旨集含む）カッコ内は当日

日本熱測定学会会員 5,000円（7,000円), 共催・協賛学協会会員 6,000 円 (8,000円), 学生会員 2,000円 (3,000円), 非会員 7,000 円 $(9,000$ 円), 非会員学生 3,000 円 (4,000円)

○懇親会 2 日 (火) 夕刻. 会費一般 6,000 円 (7,000円), 学生 3,000円（4,000円）

（）問合せ先テ101-0032東京都千代田区岩本町 1-6-7 宮沢ビル 601 日本熱測定学会事務局（TEL 03-5821-7120, FAX 03-5821-7439, E-mail : netsu@mbd.nifty.com)

URL : http://wwwsoc.nii.ac.jp/jscta/index.html

討論会の URL : http://kotai4-mc.eng.hokudai.ac.jp/kotai/ 2007JSCTA/

\section{第27回エレクトロセラミックス研究討論会 主催 日本セラミックス協会 協賛 本会ほか}

日 時：10月18日（木）～19日（金） 9：00〜 18：00

場 所：東京理科大学森戸記念館 (東京都新宿区神楽坂 4-2-2)

方テーマ エレクトロセラミックスの基礎から応用まで

(0) 一般発表 電子七ラミックス全般（合成プロセス, 物性, シミ ユレーション・評価法など)

( ) 特定セッション 1 . 薄膜（電子七ラミック薄膜に関する基礎 と応用), 2 . 誘電・強誘電・圧電セラミックス (単結晶・バル クセラミックスのプロセスと応用)，3. 高周波用セラミックス (情報化社会に応えるマイクロ波・ミリ波带用セラミック誘電 体)，4.ナノクリスタルのプロセス・評価・物性（ナノセラミ ックスに関する作製・ハンドリング・新規物性・キャラクタリ ゼーション技術・構造制御など), 5 . 環境・エネルギー（セン サ, 電池, 触媒, エネルギー関連セラミックスや無鉛化技術など)

○講演募集件数 口頭発表約 50 件, その他はポスター発表

（講演申达締切 7月20日（金）17：00必着

( )要旨締切 9 月 7 日 (金) 17：00必着

( ) 申込・問合せ先 日本セラミックス協会電子材料部会（TEL 03-3362-5231, E-mail : e-touron07@cersj.org) 詳細は http://www.ceramic.or.jp/bdenshi/index_j.html をご覧
下さい.

\section{第48 回高圧討論会}

主催 日本高圧力学会

協賛 本会ほか

日 時：11月20日（火） 22日（木）

場＼cjkstart所：倉吉パークスクエア（倉吉市䭾経寺町 212-5)

论講演募集分野 高圧力の科学と技術に関する分野：(1)高圧装 置·技術，(2)固体物性，(3)固体反応，(4)流体物性，(5)流体反応， (6)地球科学，(7)生物関連，(8)衝撃圧縮（ただし(4)，(5)，(7)には 溶液，界面および食品を含む）

○特別企画

特別講演.（鳥取大) 篠田雅人

シンポジウム 3 件企画中「装置・技術関連」,「地球科学関連」, 「生体関連物質と水溶液の高圧科学（仮題）」

○発表形式 口頭発表, ポスター発表

○講演申込 日本高圧力学会のホームページ「高圧討論会」の講演 申达フォームをご利用下さい.

○講演申込締切 7 月 6 日 (金)

()講演要旨原稿締切9 月26日（水）

締切日を過ぎた要旨原稿については, 要旨集に掲載できない

こともあります．発表論文については査読をします。

()参加登録予約締切 10月19日（金）

参加登録手続きは日本高圧力学会ホームページ「高圧討論会」 の参加申达フォームをご利用下さい.

(9)参加費 会員 4,000円, 非会員 6,000 円, 学生会員 2,000 円, 非会 員学生 3,000円（当日申込は各 1,000 円増し）要旨集 5,000 円 参加費の振込先：郵便振替（01080-7-48066 日本高圧力学会), 銀行振込（みずほ銀行出町支店 (普通) 1409296 日本高圧力学 会）

○笮親会 11 月 21 日 (水) 夕刻. 一般 7,000 円，学生 3,000 円 （）参加申込先 广 606-8125京都市左京区一乗寺清水町 16 NAKAI ビル 301 日本高圧力学会事務局（TEL \& FAX 075-721-0376, E-mail : jimu@highpressure.jp) http://www.highpressure.jp/ 詳細は日本高圧力学会ホームページの「第 48 回高圧討論会」 （http://www.highpressure.jp/forum/48/index.shtml）をご覧下 さい.

\section{The 2nd International Conference on Physics of} Solid State Ionics (2nd ICPSSI) 主催＼cjkstart第 2 回基礎系固体イオニクス国際会議組織委員会 共催 固体イオニクス学会ほか

協賛：本会ほか

日 時：12月16日（日） 19日（水）

場 所：東京工業大学すずかけ台キャンパス大学会館 （横浜市緑区長津田町 4259）

々主旨 固体イオニクス材料における超イオン伝導機構の解明を 指向し, その本質的理解のために最先端の研究成果を発表し意 見交換を行う. 結晶構造, イオン伝導ダイナミクス, 電子構造 などについて理論及び実験の立場から世界の材料基礎科学の研 究者と情報交流を深め, 固体イオニクスの基礎分野に新たな展 開をはかる.

○発表形式 口頭発表及びポスター（使用言語英語）

○論文集 Solid State Ionics の特別号 1 冊を2008年に発行

(2)発表申込期限 (予備登録) 7 月 31 日（火） 
() Abstract 提出期限（最終登録） 10 月 31 日（水）

(2) Proceedings 論文提出期限 12月31日（月）

（参加費 10 月 31 日まで。それ以降は（）内の金額

一般30,000円 (35,000円), 学生10,000円（15,000円）

（）問合せ先７226-8503横浜市緑区長津田町4259 東京工業大学 応用セラミックス研究所 阿竹徹（TEL 045-924-5343, FAX 045-924-5339, E-mail : icpssi@thermo.msl.titech.ac.jp) URL : http://thermo.msl.titech.ac.jp/ICPSSI/

(2) The 2nd International Conference on Physics of Solid State Ionics（2nd ICPSSI）事務局 ₹101-0032東京都千代田区岩本 町 1-6-7 宮沢ビル 601（TEL 03-5821-7120, FAX 03-5821-7439, E-mail : sofiel@mbd.nifty.com)

\section{第44回化学関連支部合同九州大会 共催 本会九州支部ほか 7 化学関連学協会支部}

日 時：7月 7 日（土） $9: 00 \sim 17: 10$

場 所：北九州国際会議場（北九州市小倉北区浅野3-9-30）

论特別講演（国際会議室）16：20～17：10

拡がる機能性高分子の領域（早大理工）西出宏之

代依頼講演 9：40〜16：40

1. 生理機能評価におけるモデルアッセイ系の重要性（九大院農） 松井利郎

2. 動物細胞の機能性組織培養技術の開発と代謝系臟器構築への 展開（九大院工）井嶋博之

3. 界面活性剤水溶液表面でのアルカンレンズの薄膜形成（九大 院理）松原弘樹

4. 食の安全確保におけるセンサー技術の利用（九大院農）宮本 敬久

5. 次世代リチウムイオン電池用オリビン正極とポストオリビン 正極（九大先導研）岡田重人

6. ペーパー構造体触媒による燃料電池用水素製造 (九大院農) 北岡卓也

7. 光スイッチを持った水素結合性超分子化合物の合成と物性 (佐賀大理工) 竹下道範

8. 動的共有結合化学に基づく精密高分子反応（九大先導研）大 塚英幸

去一般ポスター講演セッション：電気化学〈セッション $6>$ $14: 50$ 15:50 (イベントホール)

6_7.001 溶液中における非対称水晶振動子の共振周波数変化特性 の振る舞い（鹿児島大院理工） 小平田聡, 黒澤 茂, 吉本 稔

6_7.002 低流速 BZ 反応カオスのノイズによる秩序形成（鹿児島 大院理工）廣瀬公尚, 吉本 稔

6_7.003 気液平衡理論に基づくガス溶解度を組み込んだ高圧水電 解プロセスの数值解析 (九大工) '秋永草平, 佐々木一成, 伊藤 衡平

6_7.004 ニュートン流体中における水晶振動子の諸特性（鹿児島 大院理工）湯田有希子, 吉本 稔

6_7.005 Belousov-Zhabotinsky 反応における粘度一密度の動的挙 動（鹿児島大院理工）増田将太, 久保臣悟, 吉本 稔

6_7.006 液液界面に扔けるアミノ末端ポリアミドアミンデンドリ マーの反応挙動（長崎大工） 上野 健, 永谷広久, 相樂隆正

6_7.007 界面活性剂共存下に打けるカチオン性ポルフィリンの液 液界面吸着反応（長崎大工）岸川聡太, 永谷広久, 相樂隆正

6_7.008 脂溶性アンモニウムイオン同族体の脂質二分子膜透過現 象（鹿児島大院理工） 那須麻友子，野元 満，吉本 稔
6_7.009 両連続相マイクロエマルションを反応場とする電気化学 反応系の構築（熊本大院工）萩原佳明，國武雅司，坂田眞砂代， 石橋由香利

6_7.010 電気泳動法を用いたシリカコロイド結晶膜の作製と評価 (久留米高専, 豊橋技大) 濱上寿一, 内堀大輔, 吉村浩一, 松 田厚範

6_7.011配向性有機薄膜を有する電界効果トランジス夕の作製と 評価（九工大院生命体工）濱口修太, 吉田頼司, 門 孝, 早瀬 修二

6_7.012 電位掃引はシクロデキストリン包接ビオロゲンチオール 単分子膜作成に必要か？（長崎大院生産科学・工） 村上裕人， 植山大輔，有田勝志，千布紘子，相樂隆正

6_7.013 シクロデキストリンと長鎖ビオロゲンの錯形成と電気化 学挙動（長崎大院生産科学·工）植山大輔, 有田勝志, 村上裕 人, 相樂隆正

6_7.014４-ピリジンアルカンチオール SAM 修飾 Au(111） 電極の 表面構造の $\mathrm{pH}$ 依存性（熊本大院自然）`土山真史，西山勝彦， 谷口 功

6_7.015 表面増強赤外分光法および電気化学測定法による2-,3-,4ピリジルジスル フィド修飾 SAM の界面特性評価（熊本大院自 然）芹生浩史, 宮崎 晋, 西山勝彦, 谷口 功

6_7.016 平面脂質二分子膜の動的挙動を用いた味覚センサに関す る基礎研究（鹿児島大工）竹下瑞季, 野元 満, 吉本 稔

6_7.017 In situ蛍光顕微イメージングによる Au(111) 電極表面 上有機薄膜の電位応答挙動の追跡（長崎大院生産科学 - 工）後 藤大作，相樂隆正

6_7.018 金電極上のナフィオン超薄膜におけるビオロゲンの電気 化学応答（長崎大工） 嘉数あい, 相樂隆正

6_7.019 ポリ（N-メチルピロール）/ナフィオン複合ポリマー上 に電析した白金微粒子のエタノール酸化活性（山口大院理工） 森田昌行, ${ }^{\circ}$ 中井優志, 吉本信子, 江頭 港

6_7.020 ポリ（N-メチルピロール）で被覆した炭素粒子上への白 金微粒子触媒の調製（山口大院理工）森田昌行, 渡部陽介, 吉 本信子，江頭 港

6_7.021 金一銅合金ナノ粒子修飾電極を用いたグルコースの電気 化学的触媒酸化反応と燃料電池への応用 (熊本大院自然) ○多恵 馬裕香, 長嶋慎人, 冨永昌人, 谷口 功

6_7.022 金ナノ粒子修飾電極を用いたVOCガスセンサの応答特 性および応答原理（熊本大院自然）山名来充恵, 冨永昌人, 谷 口 功

6_7.023 アルカンチオール保護金ナノ粒子の単結晶 $\mathrm{Au}(111)$ 電 極上での電位応答挙動（長崎大院生産科学・工）`今崎克太郎, 相樂隆正

6_7.024 金ナノ粒子を用いた爆発物検知のための超高感度 SPR七 ンサ（九大）川口俊一, Dhesingh Ravi Shankaran, Sook Jin Kim, 松本 清, 都甲 潔, 三浦則雄

6_7.025エタノールを直接燃料とした燃料電池の高出力化〜ナノ 粒子添加によるエタノール酸化触媒の検討（九工大院生命体工） 神杉一吉, 白石剛之, 朴 男信, 飯塚恵太, 原 嘉孝, 門 孝, 早瀬修二

6_7.026 白金塩含有液晶/カーボン混合物からのPtナノ構造体担 持カーボンの合成と評価（宮崎大工） 林 祐一, 魚田将史, 酒 井 剛，木島 剛

6_7.027 熱刺激電流による色素増感太陽電池の電荷分離界面に関 する考察（九工大院生命体工, 新日化） 野間裕介, 門 孝, 尾 
达裕平, 河野 充, 山口能弘, 早瀬修二

6_7.028 電荷分離界面制御による色素増感太陽電池の高効率化 （九工大院生命体工，新日化）岡田圭介, 西村照美, 柏 洋平, 渡嘉敷真哉, 尾込裕平, 河野 充, 山口能弘, 早瀬修二

6_7.029 酸化チタン微粒子の光触媒特性に及ぼすその表面へのプ ラズマCVD薄膜層形成効果（北九州高専）`神谷 舞，岩澤尚 子，園田達彦，山根大和，松嶋茂憲，中村裕之，山田憲二

6_7.030 色素増感太陽電池のアノード薄膜構造・特性に及ぼす低 温プラズマ処理酸化チタン微粒子の導入効果（北九州高専） ${ }^{\circ}$ 松 木健祐, 園田達彦, 山根大和, 松嶋茂憲, 中村裕之, 山田憲二

6_7.031 アルミナポーラス薄膜/導電性高分子/イオン液体複合電 荷移動媒体を用いた色素増感太陽電池（九工大院生命体工） 稲 員ふ2, 幸後 健, 尾达裕平, 坂口昇平, 加藤岳仁, 高嶋 授, 金藤敬一, 早瀨修二

6_7.032 有機半導体ハイブリッド太陽電池の性能向上に関する研 究（九工大院生命体工）緒方大輔，原 嘉孝，高嶋 授，金藤 敬一, 早瀬修二

6_7.033 色素増感太陽電池用透明導電膜に関する研究 (九工大工, 山口県産技七） ${ }^{\circ}$ 田畑康二, 黒田佑一, 大久保末廣, 白土竜一, 村中武彦

6_7.034 色素増感太陽電池におけるチタニア多孔質膜の検討（九 工大工）古賀雄太，新谷 靖，大久保末廣，白土竜一

6_7.035 遷移金属ドープ $\mathrm{TiO}_{2}$ 薄膜電極による色素増感太陽電池 の変換効率の改善（北九州高専）宮島正吾，園田達彦，山根大 和，松嶋茂憲，中村裕之，山田憲二

6_7.036 酸化チタン厚膜電極を用いた色素増感太陽電池の I-V 特 性（北九州高専）中川大五郎, 小畑賢次, 松嶋茂憲

6_7.037 色素増感太陽電池におけるチタニア電極の小粒径化の効 果（九工大情報工）池田修平, 野仲良, 安田 敬, 荒川 等, 古川昌司

6_7.038 Ru系色素のシミュレーション研究（九工大院生命体工） 柏 洋平, 門 孝, 早瀬修二

6_7.039 新規有機薄膜太陽電池の構築（九工大院生命体工）原 嘉孝, 緒方大輔, 高嶋 授, 金藤敬一, 早瀬修二

6_7.040 含水酸化チタンの電気伝導特性（九大院工・未来化セ） 梶谷智史, 松本広重, 石原達已

6_7.041 酸化物複合膜を電極とした色素増感太陽電池のインピー ダンス測定（有明高専, 九工大工）伊藤靖浩, 古庄啓太郎, 石 丸智士，木山拓哉, 大久保末廣, 白土竜一

6_7.042 光触媒色素分解反応に及ぼす溶存塩の影響（九大院総合

理工）川口裕一朗，蒔田 慎，原田 明

6_7.043 四級アンモニウム塩イオン液体を用いた色素増感太陽電 池用ゲル電解質（山口大院理工）森田昌行, ‘赤木章吾, 吉本信 子, 江頭 港

6_7.044 細胞増殖および交流電位印加による膜障害に及ぼすカー ボンナノチューブの影響（熊本大院自然）永石祥一朗, 冨永昌 人, 谷口 功

6_7.045 カーボンナノチューブ合成基板電極とグルコースオキシ ダーゼとの直接電子移動反応（熊本大院自然）野村真也, 冨永 昌人, 谷口 功

6_7.046 Miniature SPR Immunosensor Equipped with Multichannel Flow-cell for Simultaneous Detection of Multiple 2,4-D Samples (Kyushu Univ., Omron) ${ }^{\circ}$ Sook Jin KIM, Kauveri Vengatajalabathy GOBI, Hiroyuki IWASAKA, Hiroyuki TANAKA, Norio MIURA
6_7.047 ビリルビンオキシダーゼー電極間の直接電子移動反応に 及ぼす電極表面官能基の影響（熊本大院自然）`大谷まい，冨永 昌人，谷口 功

6_7.048 コアサイズの異なるフェリチンの基板上へのマイクロパ ターニング（熊本大院自然）宮原勝也, 冨永昌人, 谷口 功

6_7.049 フェリチン構造の温度依存性の電気化学的解析（熊本大 院自然) 中尾航大，副島和樹，冨永昌人，谷口 功

6_7.050 バクテリアルシフェラーゼを用いた電気化学発光系の構 築と流れ系への展開 (九大院理) 崎信哉, 中嶋真也, 竹原 公

6_7.051 カーボン電極上のフルクトースデヒドロゲナーゼの直接 電子移動反応と生物然料電池への応用（熊本大院自然）白木原 千春，岸川茉莉，大谷まい，冨永昌人，谷口 功

6_7.052 多酵素系糖 - 空気燃料電池の開発（熊本大院自然）`金 子詩織, 岸川茉莉, 大谷まい, 冨永昌人, 谷口 功

6_7.053 Receptor Based Affinity Biosensors for Biomedical Applications (Kyushu Univ., JSPS, J.N.V Univ.) ${ }^{\circ}$ Dhesingh RAVI SHANKARAN, Sook Jin KIM, Sunita KUMBHAT, K. Vengatajalabathy GOBI, Toshikazu KAWAGUCHI, Norio MIURA

6_7.054 イオン液体，1-ブチル 3-メチルイミダゾリウムビストリ フルオロメタンスルホニルイミド中の $\mathrm{Sr}^{2+}$ および $\mathrm{Cs}^{+}$の溶媒和 (九大院理) 山口大志, 藤井健太, 神崎 亮, 梅林泰宏, 石黒 慎一

6_7.055 イオン液体の基礎物性に関する研究（九工大院生命体工） ○西村昭美，飯塚恵太，佐藤順平，門 孝，早瀬修二

6_7.056 水熱法による二酸化マンガンの合成（佐賀大理工） 川 口賢一，磯野健一，中村博吉，野口英行

6_7.057 NASICON厚膜を用いたフォトルミネッセンス素子（九 工大工） 小熊行祥, 高瀬聡子, 清水陽一

6_7.058 赤色応力発光体 ZnS:Mn,Teの開発（九大, 産総研, JSTCREST) 鳥井岳人, 徐超男, 山田浩志, 今井祐介, 寺崎 正, 安達芳雄, 西久保桂子

6_7.059 電気化学法を用いた UV -オゾン処理による有機分子分 解評価 (熊本大院自然) 平田徳史, 冨永昌人, 谷口 功

6_7.060 電気泳動析出 $\alpha$ コバルトフタロシアニンの酸素還元触媒 特性（九工大工）中島章治, 高瀬聡子, 岩屋 涉, 荒木孝司, 清水陽一

6_7.061 ナノ多孔性 $\mathrm{LiFePO}_{4} / \mathrm{C}$ 複合体を用いた高出力リチウムイ オン二次電池用電極の開発（長崎大工・院生産科学, 産総研） 山田博俊, 鍋吉祥平, 森口 勇, 工藤徹一

6_7.062 ナノ多孔性 $\mathrm{V}_{2} \mathrm{O}_{5}$ /カーボン複合電極の創製と高出力リチ ウム挿入 ·脱離特性（長崎大院生産科学 - 工, 産総研) ${ }^{\circ}$ 田川和 樹, 小松真治, 山田博俊, 森口 勇, 工藤徹一

6_7.063 サブミクロンオーダーの球状多孔質構造を有する酸化物 微粒子の調製とガスセンサへの応用（長崎大院生産科学・工）

橋本麻由, 兵頭健生, 清水康博, 江頭 誠

6_7.064 メソポーラス $\mathrm{SnO}_{2}$ 粉末の形状制御とガスセンサ特性 （長崎大院生産科学 -工） ${ }^{\circ}$ 林 正裕, 兵頭健生, 清水康博, 江 頭 誠

6_7.065 硫酸賦活したジルコニア酸化物メゾ多孔体のプロトン伝 導特性（長崎大院生産科学・工, 産総研） 平野泰寛, 山田博俊, 森口 勇, 工藤徹一

6_7.066 グラファイト化した多孔カーボンの創製とリチウムイン ターカレーション特性（長崎大院生産科学・工, 産総研）渡辺 裕子, 山田博俊, 森口 勇, 工藤徹一 
6_7.067 マクロポーラス貴金属膜を用いたバイオセンサ用電極の 開発（長崎大院生産科学・工）吉田衣里，兵頭健生，清水康博， 江頭 誠

6_7.068 メソ・マクロポーラス酸化スズの調製とガス検知特性 (長崎大院生産科学・工) 原 陸洋, 兵頭健生, 清水康博, 江 頭 誠

6_7.069 多孔カーボン/Ptナノ複合電極の酸素還元特性（長崎大 院生産科学 -工）加藤圭一, 平井泰樹, 山田博俊, 森口 勇

6_7.070 Highly sensitive and selective detection of picomolar concentrations of small molecular fragrants by surface plasmon resonance sensing (KASTEC, Kyushu Univ.) ${ }^{\circ}$ K. Vengatajalabathy Gobi, Kiyoshi Matsumoto, Kiyoshi Toko, Hidekazu Ikezaki, Norio Miura

6_7.071 PCBモニタリングのための最適クリーンアップ材の探索 と分離特性（三菱重工長崎研, 長菱エンジニアリング, 九大産 学連携セ, 昭和電工) 澤津橋徹哉, 馬場恵吾, 三浦則雄, 篠田 晶子

6_7.072 固体電解質型 $\mathrm{CO}_{2}$ センサに用いる検知極補助層の多孔質 化（長崎大院生産科学・工）森尾昌隆, 兵頭健生, 清水康博, 江頭 誠

6_7.073 プロペンの高感度・高選択的検知用複素インピーダンス 応答型センサ（九大院総合理工・産学連携セ, 国立環境研）和 間良太郎，内山政弘，三浦則雄

6_7.074 Planar $\mathrm{NO}_{2}$ Sensor Based on Stabilized Zirconia and Nano-gold Sensing Electrode (KASTEC, Kyushu Univ.) - Vladimir V. PLASHnitsa, Taro UEDA, Perumal ELUMALAI, Norio MIURA

6_7.075 ペロブスカイト型酸化物／カーボンクロス電極によるリ ン酸イオンセンサ（九工大工） 松本俊和, 高瀬聡子, 清水陽一 6_7.076 環境モニタリングを目指した混成電位型炭化水素センサ （九大院総合理工・産学連携七, 国立環境研）`森 峻司, 和間 良太郎, 内山政弘, 三浦則雄

6_7.077 メタンの選択的検知のための混成電位型安定化ジルコニ アセンサ（九大院総合理工・産学連携セ） ${ }^{\circ}$ 上田太郎, エルマレ イペルマル，ブラディミル プラシニッァ，三浦則雄

6_7.078 マイクロプラズマ重合薄膜を利用したガスセンサの開発 （鹿児島大院理工） 松尾剛志, 牧迫智之, 黒澤 茂, 吉本 稔

6_7.079 めっき法を用いた室温作動型オプティカル水素センサの 作製と評価（久留米高専，長岡技大）濱上寿一, 呙堀 大輔, 森 将来, 栗原 丈, 高田雅介

6_7.080 ラメラ状 $\mathrm{WO}_{3}$ の微細構造制御による $\mathrm{NO}_{2}$ センサの高性 能化 (九大総合理工) 西山 綾, 湯浅雅賀, 木田徹也, 島ノ江 憲剛，山添 曻

6_7.081 Supercapacitive characteristics of Metal oxide/Single walled carbon nanotube composites (九大, JST) ${ }^{\circ}$ Vinay GUPTA, Norio MIURA

6_7.082 Supercapacitive and QCM characteristics of electrochemically deposited Co-based material (Kyushu Univ.) 'Perumal ELUMALAI, Teruki KUSAHARA, Vinay GUPTA, Norio MIURA

6_7.083 フェノール樹脂/シリカハイブリッド材料を用いた多孔 カーボンの合成と電気二重層キャパシタ特性（長崎大院生産科

学・工） 田浦慶二, 渡辺裕子, 山田博俊, 森口 勇

6_7.084 黒鉛系カーボンへのアニオン挿入を利用するハイブリッ ドキャパシタ（九大工・院工・未来化セ，マツダ技研，佐賀大）
横山友嗣, 下坂暢明, 松本広重, 藤田弘輝, 對尾良則, 芳尾真 幸，石原達己

6_7.085 電析法により作製したコバルト系電極の電気化学キャパ シ夕特性の改善（九大院総合理工・産学連携七, JST）遠山 洋, 草原輝樹, Vinay Gupta, 三浦則雄

6_7.086 新規スルホニウム塩の蓄電デバイス用電解液への応用 (山口大院理工，三新化学) 芦浦 正, 吉本信子, 江頭 港, 森田昌行, 寺田直樹, 高下勝滋

6_7.087 リチウム過剩法による $\mathrm{LiMnPO}_{4}$ 微粒子の作製とそのリ チウム二次電池正極特性（九大総合理工 - 先導研, JST) 石井 潤志，川村哲也，土井貴之，岡田重人，山木準一

6_7.088 リチウム二次電池用 $\mathrm{LiNi}_{0.5} \mathrm{Mn}_{1.5} \mathrm{O}_{4}$ 薄膜正極における耐高 電位保護膜の検討 (九大総合理工 - 先導研) 影浦淳一, 土井貴 之, 岡田重人, 山木準一

6_7.089 非晶質 $\mathrm{V}_{2} \mathrm{O}_{5}$ 薄膜の作製と高速リチウムインターカレー ション特性（長崎大工・院生産科学, 産総研） 小松真治, 田川 和樹, 山田博俊, 森口 勇, 工藤徹一

6_7.090 Cu 及びLiイオン伝導体と絶縁体のナノ複合化とイオン 伝導特性（長崎大院生産科学·工, 産総研）霖田俊介, 山田博 俊, 森口 勇, 工藤徹一

6_7.091 イミド系添加剤を含む電解液を用いたリチウムイオン電 池のエネルギー密度の改善（佐賀大理工）吉田雄一, 中山佳苗, 中谷 翔, 中村博吉, 野口英行

6_7.092 $\mathrm{MF}_{3}$ 型正極における $\mathrm{Li}$ および $\mathrm{Na}$ 二次電池特性（九大総 合理工 · 先導研) `西嶋 学, Irina D. Gocheva, 土井貴之, 岡 田重人，山木準一

6_7.093 界面制御型噴霧熱分解法による $\mathrm{LiMn}_{2} \mathrm{O}_{4}$ 微粒子の作製と そのリチウム二次電池正極特性（九大総合理工 - 先導研）。尋 勉, 土井貴之, 岡田重人, 山木準一

6_7.094 中性子広角散乱実験によるプロピレンカーボネート中の リチウムイオン構造解析 (九大院理) 亀田恭男, 梅林泰宏, 竹 内宗孝，`モハンマド アブドゥル ワハブ，福田修平，石黒真一， 佐々木基弥，天羽優子，臼杵 毅

6_7.095 ナノピラー型構造を有する高出力二次電池用 $\mathrm{LiNiO}_{2}$ 及び $\mathrm{NiO}$ 電極の創製とリチウム挿入 /脱離特性（長崎大院生産科 学・工）和泉真哉人, 鍋吉祥平, 山田博俊, 森口 勇

6_7.096 $\mathrm{Li}_{2} \mathrm{MgCl}_{4}$ /メゾポーラスアルミナ複合体の作製とリチウ ムイオン伝導特性（長崎大院生産科学 - 工）猿渡 勇, 山田博 俊, 森口 勇

6_7.097 Li 電池用 Li-Fe-P三元系ガラス正極の電池特性（九大総 合理工 · 先導研) `早稲田哲也, 土井貴之, 岡田重人, 山木準一 6_7.098 ナシコン型 $\mathrm{Na}_{3} \mathrm{~V}_{2}\left(\mathrm{PO}_{4}\right)_{3}$ を正負極に用いたナトリウムイ オン二次電池特性（九大総合理工・先導研）野口良典, 小林栄 次, 土井貴之, 岡田重人, 山木準一

6_7.099 メカニカルミリング法により調製した黒鉛ーマグネシウ ム複合電極のリチウムイオン電池負極特性（山口大院理工）森 田昌行, ‘松尾雄太, 吉本信子, 江頭 港

6_7.100 リチウム二次電池用 $\mathrm{LiCoO}_{2}$ 微粒子正極の熱安定性（九 大総合理工 - 先導研) 竹林義友, 土井貴之, 岡田重人, 山木準一 6_7.101 SOFCの発電特性に及ぼす温度サイクルの影響（九大院 工, 九州電力, 水素利用技研七) 白鳥祐介, 南園隆広, 神後直 樹，佐々木一成

6_7.102 バイオガス供給時のSOFCの発電特性に及ぼす燃料不純 物の影響（九大院工, 水素利用技研セ） 白鳥祐介, 佐々木一成 6_7.103 燃料電池用高分子膜電極接合体の作製（九工大工）岩 
永卓朗，高瀬聡子，清水陽一

6_7.104 PEFCにおける Floodingの可視化と数值計算（九大院工， 水素利用技研セ） 益田啓光, 伊藤衡平, 佐々木一成

6_7.105 アノード支持型 SOFC の被毒耐久性に関する研究（九大 院工，水素利用技研七）内川宗幸， ○㴊香織，大嶋敏宏，白鳥 祐介，伊藤衡平，佐々木一成

6_7.106 SOFCの被毒耐久性における燃料不純物種依存性（九大 院工，水素利用技研七）芳賀健吾，足立修一，白鳥祐介，伊藤 衡平，佐々木一成

6_7.107 噴霧熱分解法を用いたSOFCアノード材料の調製と発電 特性（九大院工，水素利用技研七）山本隼也，白鳥祐介，伊藤 衡平, 佐々木一成

6_7.108 急速還元法によるPt-Ir系合金担持カーボンの合成と燃 料電池用カソードへの適用（宮崎大工）`今井春幸，岸下哲平， 酒井 剛, 木島 剛

6_7.109 灯油供給型 SOFC の改質触媒に関する研究（九大院工, 水素利用技研七) 西岡 恒, 今村直史, 大嶋敏宏, 白鳥祐介, 伊藤衡平，佐々木一成

6_7.110 表面制御炭素ナノ繊維を担体として用いたPEFC 電極触 媒に関する研究（九大院工，水素利用技研セ） 野田志雲, 岩倉 大典, 竹内 翔, 周 致霆, 白鳥祐介, 伊藤衡平, 佐々木一成

6_7.111 炭素ナノ繊維担持PEFC 合金触媒の調製と電気化学特性 （九大院工，水素利用技研七）竹内 翔, 野田志雲, 白鳥祐介, 伊藤衡平, 佐々木一成

6_7.112 酸化物担体を用いたPEFC 電極触媒に関する研究（九大 院工, 水素利用技研セ） 正生明宏, 黒木貴士, 川副雄大, 周 致霆, 白鳥祐介, 伊藤衡平, 佐々木一成

6_7.113 Cathode properties of NaMF3 prepared by mechanochemical synthesis（九大総合理工・先導研） ${ }^{\circ}$ Irina Gocheva, 西嶋 学, 土井貴之, 岡田重人, 山木準一

6_7.114 高コバルト含有層状Li-Co-Ni-Mn-O 系材料の電気化学特 性（佐賀大理工） 大賀涼太, 広池政雄, 磯野健一, 中村博吉, 野口英行

6_7.115 PSA用酸素吸着剤としての Sr-Fe系ペロブスカイト型酸 化物（九大院総理工 - 産学連携セ, 吸着技術工業） ${ }^{\circ}$ 山下英男, 泉 順, 三浦則雄

6_7.116 金属空気二次電池用 $\mathrm{Fe}$ 薄膜負極の電気化学特性（九大 総合理工 · 先導研) 林 洋志, 土井貴之, 岡田重人, 山木準一 6_7.117 アミロースヨウ素錯体を用いたイオンパス構築の試み （九工大院生命体工, 関東新天然瓦斯, 江崎グリコ) 幸後 健, 早瀬修二, 海宝龍夫, 田口 充, 細谷佳代

6_7.118 急速沈殿法による高比表面積水酸化ニッケルの調製と正 極材料への応用（宮崎大工）藤田幸二, 宮崎 誠, 酒井 剛, 木島 剛

6_7.119 アルコール系電解液中でのチタンのアノード分極挙動に 及ぼす溶媒組成の影響（山口大院理工, 山口産技セ, 三和産業) 森田昌行, ${ }^{\circ}$ 大上一真, 吉本信子, 江頭 港, 村中武彦, 弘中大久

6_7.120 固体高分子形水電解セルにおける差圧変化などが性能に 及ぼす影響（九大院工，水素利用技研七）黑田 宙, 伊藤衡平, 佐々木一成

6_7.121 圧電性窒化アルミニウム薄膜の高温インピーダンス特性 （産総研九州）西島 大，田原竜夫，秋山守人

外外国人研究者交流シンポジウム (International Symposium for an interchange of foreign researchers)（外国人研究者交流ポ スター発表 [抜粋]）＜セッション 3>11：20～12：20（イベ
ントホール)

3_外.008 Highly sensitive and selective detection of picomolar concentrations of small molecular fragrants by surface plasmon resonance sensing (KASTEC, Kyushu Univ.) ${ }^{\circ} \mathrm{K}$. Vengatajalabathy Gobi, Kiyoshi Matsumoto, Kiyoshi Toko, Hidekazu Ikezaki, Norio Miura

3_外.009 Miniature SPR Immunosensor Equipped with Multichannel Flow-cell for Simultaneous Detection of Multiple 2,4-D Samples (Kyushu Univ., Omron) ${ }^{\circ}$ Sook Jin KIM, Kauveri Vengatajalabathy GOBI, Hiroyuki IWASAKA, Hiroyuki TANAKA, Norio MIURA

3_外.010 Cathode properties of NaMF3 prepared by mechanochemical synthesis（九大総合理工・先導研） ${ }^{\circ}$ Irina Gocheva, 西嶋 学, 土井貴之, 岡田重人, 山木準一

3_外.011 Planar $\mathrm{NO}_{2}$ Sensor Based on Stabilized Zirconia and Nano-gold Sensing Electrode (KASTEC, Kyushu Univ.)

Vladimir V. PLASHNITSA, Taro UEDA, Perumal ELUMALAI, Norio MIURA

3_外.012 Receptor Based Affinity Biosensors for Biomedical Applications (Kyushu Univ., JSPS, J.N.V Univ.) ${ }^{\circ}$ Dhesingh RAVI SHANKARAN, Sook Jin KIM, Sunita KUMBHAT, K. Vengatajalabathy GOBI, Toshikazu KAWAGUCHI, Norio MIURA

3_外.013 Supercapacitive characteristics of Metal oxide/Singlewalled carbon nanotube composites (九大, JST) ${ }^{\circ}$ Vinay GUPTA, Norio MIURA

3_外.014 Supercapacitive and QCM characteristics of electrochemically deposited Co-based material (Kyushu Univ.) 'Perumal ElUMALAI, Teruki KUSAHARA, Vinay GUPTA, Norio MIURA

○他のセクションなどについての詳細は，大会HP（http:// chempro.env.kitakyu-u.ac.jp/ 44godo/）参照.

(〕参加登録費 参加費は無料. 発表登録料として, ポスター発表 1 件につき，2,500円（予稿集 1 冊を含む）を当日受付にて徵収. 発表者以外の参加者には予稿集を 1,500 円で当日販売.

○懇親会（17：30～19：00）北九州国際会議場レストラン 「ラ・プラージュ」にて. 会費一般 4,000円, 学生 1,500 円（当日 徵収)

()問合せ先 第44回化学関連支部合同九州大会実行委員会 代表世話人：櫻井和朗（E-mail：godo44@env.kitakyu-u.ac.jp, TEL 093-695-3294, FAX 093-695-3390)

電気化学会九州支部庶務幹事 : 相樂隆正（E-mail：sagara@ nagasaki-u.ac.jp, TEL \& FAX 095-819-2676)

\section{お知らせ}

\section{産業技術総合研究所博士研究員募集}

募集人員：博士研究員（ポストドクトラルフェロー）

所属：エネルギー技術研究部門

専門分野：電気化学，エネルギー材料化学，ナノ材料等

研究内容：固体電解質, 電極活物質等の新材料開発

応募資格：博士の学位を有するもの. 国籍・性別問わず

着任時期：決定後, 出きるだけ早く

提出書類：履歴書および発表論文リスト

応募締切：2007年 9 月 14 日（金）

書類送付・問合せ先：=305-8568 つくば市梅園 1-1-1 
中央第 2 産業技術総合研究所エネルギー技術研究部門 本間＼cjkstart格(TEL 029-861-5648，E-mail：i.homma@aist.go.jp)

\section{7 年度 株式会社 KRI 研究公募}

エネルギー・環境，材料，分析・計測の各技術で独創的なアイ デアに基づいた研究の促進や発展を通して, 科学技術の発展に寄 与し，産業において有益である研究へと展開させる礎を構築する ことを目的に次のとおり公募を行います。

募集対象分野：（1）エネルギーの変換・貯蔵技術，環境関連技 術，（2）高分子材料や無機材料，七ラミックス，金属，天然物 あるいはこれらを複合する材料系とその作製プロセス，（3）ナ ノレベルでの先端的分析評価技術やセンサー・計測技術，に関 する基礎研究.

要 件：（1）自ら計画・提案し, 自律的に実行できるテーマ, (2) 研究期間中あるいは終了後に, KRI と共同で応用研究を推 進することに同意し協力できるテーマ.

研究期間：2007年 10 月〜 2008年 3 月

応募資格：大学や研究機関に所属する新進気鋭の研究者

委託金額：1 件あたり 200 万円を上限

募集期間：2007年 6 月 1 日 2007年 7 月 17 日必着

応募方法：申請書 (HPよりダウンロード)を E-mail と郵送で提出 問合せ・送付先：応募の詳細は http://www.kri-inc.jp/をご覧下さ い. $\overline{7} 600-8813$ 京都市下京区中堂寺南町 134 (株) KRI経営企画 部 東野有花（TEL 075-315-9242, FAX 075-322-6820, Email : koubo@kri-inc.jp)

\section{株式会社豊田中央研究所 研究者募集}

・会社概要：トヨタグループ各社の出資により基礎研究から, 応 用・開発まで幅広い研究を行っています。トヨタグループや世 界の研究機関と連携し, エネルギー, 環境/安全・人間/機械/ システムエレクトロニクス/材料において重点的に研究活動を 行っています。

·公募人員：正社員 1 名

- 職務内容 : 二次電池 (特に $\mathrm{Li}$ 電池) 開発, 二次電池全般にわた る基礎研究

-応募資格：職務内容の分野において経験を有する修士以上の方

•着任時期：2007年 7 月 1 日以降（相談に応じます）

- 提出書類 : 職務内容を明記の上, 以下の書類をお送り下さい.

(1) 履歴書 (写真貼付), (2)職務歴 (研究業績リスト), (3)論文リス 卜，主要論文別刷（コピーでも可）

秘密は厳守致します。応募書類は返却致しません.

- 応募書類送付 - 問合せ先 : ₹ 480-1192愛知県長久手町大字長湫 字横道 41-1 (株豊田中央研究所採用担当：羽田, 宮崎 (TEL 0561-63-6509, E-mail : saiyo@mosk.tytlabs.co.jp)

URL : http://www.tytlabs.co.jp/

\section{産業技術総合研究所特別研究員募集}

募集人員 : 特別研究員 (ポスドク)

所属：エネルギー技術研究部門（産総研つくば中央第 2 )

専門分野: 電気化学, 化学材料, 応用化学等

給与 与 時給制 2,200 円，2,350円，2,500円

(産総研規程により決定)

待遇：当所規程により有給休暇制度，通勤手当制度有り．
社会保険完備.

研究内容：（1）新規リチウム電池材料の研究開発，（2）ナノ機能 性材料や超撥水界面や色素増感型太陽電池などの開発

応募資格：博士の学位を有するもの

着任時期：平成 19 年 6 月 1 日以降のできるだけ早く

提出書類：履歴書 (写真貼付), 博士号取得を証明できる書類, これまでの研究概要, 業績リスト（紙上発表, 口頭発 表, 知的財産権, その他)

選考方法：書類選考および面接試験

応募締切：採用者決定次第終了

書類送付・問合せ先：干 305-8568つくば市梅園 1-1-1 産業技術総 合研究所エネルギー技術研究部門 周 豪慎 (TEL 029-861-5795, E-mail : hs.zhou@aist.go.jp)

\section{第62 回新電池構想部会}

日 時：7月17日（火） $13: 00 \sim 17: 00$

主催 本会電池技術委員会

場 所：メルパルク大阪 カナーレ 5 階（大阪市淀川区宮原 4-2-1）

URL http://www.mielparque.or.jp/osk/osk01.html

記講演主題：放射光を利用する燃料電池 in situ 解析

1. In-situ 時間分解XAFSによる $\mathrm{Pt} / \mathrm{C}$ 燃料電池カソード触媒の 解析 (トヨ夕自動車) 村田成亮

2. 時分割 XRD およびXAFSを用いた燃料電池触媒表面構造の in situリアルタイム観測（日本電気）今井英人

3. XAFS 測定による燃料電池電極反応機構解明（京大人環）内 本喜晴

○参加費（資料 $\cdot$ 消費税含む）

一般 5,000 円（電池技術委員会会員および学生は無料）

(9)申込方法 氏名, 所属および連絡先を明記のうえ, 下記世話人 までE-mail またはFAXで7月 3 日（火）までにお申し込み下 さい.

○过先 テ 563-8577池田市緑丘1-8-3 産業技術総合研究所ユビ キタスエネルギー研究部門 安田和明 (E-mail : k-yasuda @aist.go.jp, TEL 072-751-9653, FAX 072-751-9629)

\section{第17回電極材料研究会} 主催 本会電解科学技術委員会

日 時：7月19日（木）

場 所：埼玉大学総合研究棟 1 階シアター教室

（さいたま市桜区下大久保 255）

○講演申込締切6月16日（土）

講演題目, 発表者氏名 (講演者 $\bigcirc$ ), 所属, 連名者, 連絡先 (TEL, FAX, E-mail) を記入の上, 下記宛お申し込み下さい.

( 講演予稿締切 7 月 2 日（月）

○参加予約申込締切 7 月13日（金）

○参加費（資料含む，当日受理）電解科学技術委員会会員無料, 一般 3,000 円，学生 1,000 円

○懇親会 講演会終了後, 学内のきゃら亭にて予定

() 申达先７338-8570さいたま市桜区下大久保255 埼玉大学工 学部応用化学科 小林秀彦 (TEL 048-858-3501, FAX 048-8583501, E-mail : hikoba@apc.saitama-u.ac.jp) http://denkai.electrochem.jp 